\title{
Two Cases of STAT6-Positive, Primary
}

\section{Conjunctival Giant Cell-Rich Solitary Fibrous} Tumour (Giant Cell Angiofibroma) with Some Unusual Histological Features

\author{
Hardeep Singh Mudhar ${ }^{a}$ Madalina Pavel ${ }^{b}$ Andrew K.K. Chung ${ }^{b}$ \\ Thomas Elliott Jackson ${ }^{c}$ \\ ${ }^{a}$ National Specialist Ophthalmic Pathology Service (NSOPS), Department of Histopathology, Royal Hallamshire \\ Hospital, Sheffield, UK; ${ }^{b}$ Cornea and External Disease Service, Department of Ophthalmology, Pinderfields Hospital, \\ Wakefield, UK; ${ }^{C}$ Department of Ophthalmology, Worcestershire Royal Hospital, Worcester, UK
}

\section{Established Facts}

- Giant cell-rich solitary fibrous tumour (GCR-SFT) (giant cell angiofibroma) is a well-described soft tissue tumour that classically occurs in the orbit but very rarely presents in the conjunctiva.

- GCR-SFT is positive immunohistochemically for STAT6, including the tumour giant cell nuclei.

\section{Novel Insights}

- We describe two cases of a unilateral inferior bulbar conjunctiva GCR-SFT with clear immunohistochemical demonstration of STAT6 positivity of the spindle, ovoid, and giant tumour cells at this location.

- In one case, the giant cells resembled Touton giant cells with possible confusion with the histology of juvenile xanthogranuloma.

- The same case showed a prominent stromal spindle melanocytic population, representing a likely collision with a subepithelial nevus.

\section{Keywords}

STAT6 · Giant cell angiofibroma · Solitary fibrous tumour · Giant cell-rich solitary fibrous tumour · Conjunctiva

\section{Abstract \\ An 84-year-old male presented with a history of a slowly growing lesion beneath the right lower lid. Examination showed a right-sided mass in the inferior bulbar conjunctiva,}

measuring approximately $10 \times 6 \mathrm{~mm}$. The lesion was excised and showed a giant cell-rich solitary fibrous tumour (GCRSFT) with pseudo-vascular spaces with benign cytology, with STAT6, expressed in the spindle, ovoid, and tumour giant cells. A second case, a 26-year-old white female, presented with a 12-month history of a gradually expanding lesion in left inferior bulbar conjunctiva. Examination showed a well-defined, dome-shaped pink fleshy mass of $10 \times 7 \times$ $2 \mathrm{~mm}$, on the inferior bulbar conjunctiva and abutting the karger@karger.com

(c) 2020 S. Karger AG, Basel

www.karger.com/oop

Karger ${ }^{\prime}=$
Hardeep Singh Mudhar

National Specialist Ophthalmic Pathology Service (NSOPS)

Department of Histopathology, E-Floor, Royal Hallamshire Hospital

Glossop Road, Sheffield S10 2JF (UK)

hardeep.mudhar@nhs.net 
inferior fornix. Excision followed by histology showed a similar appearance to the first case except that the multinucleate giant cells closely resembled Touton giant cells and did not show the rather hyperchromatic crowded nuclei of the giant cells observed in the first case. No pseudo-vascular spaces were identified. The tumour cells, including the Touton-like multinucleate giant cells, displayed nuclear positivity for STAT6. An unexpected feature was the presence of a Melan A- and Sox10-positive population amongst the GCRSFT, postulated to be a subepithelial melanocytic nevus colliding with the GCR-SFT.

(C) 2020 S. Karger AG, Basel

\section{Introduction}

In 1995, Dei Tos et al. [1] were the first to report giant cell angiofibroma (GCA) of the orbit in 7 cases. Since the original description, the tumour has been described at many extra-orbital locations. GCA is now regarded as a giant cell-rich histological variant of solitary fibrous tumour (GCR-SFT) with no prognostic implications. Whilst SFT and GCA are common in the orbit, it is very rare to encounter these lesions solely within the conjunctiva without an orbital component [2-5]. We describe two cases, both from the inferior bulbar conjunctiva which histologically were GCR-SFT, showing nuclear expression of STAT6 protein within the nuclei of the tumour cells and in the tumour giant cells. One case showed Touton-like giant cells and unusually showed prominent numbers of benign spindle cell melanocytes amongst the tumour, the significance of which is discussed.

\section{Case Report}

\section{Case 1}

An 84-year-old white male presented with a several years' history of a lesion growing on the right inferior bulbar conjunctiva that had started to affect his field of vision, especially on down gaze (Fig. 1a). The swelling had been increasing in size gradually, without ocular pain or bleeding. There was no history of ocular trauma or surgery. On examination, a right-sided oval shaped, pink coloured, pedunculated lesion on the inferior part of the bulbar conjunctiva was present, measuring approximately $10 \times 6 \times 6 \mathrm{~mm}$. It was well demarcated with a smooth surface. The only other significant finding was bilateral moderately dense cataracts. The lesion was excised. The patient remains tumour free to date (followup period 12 months).

Histopathological Findings

The histology showed a well-defined, non-encapsulated neoplasm (Fig. 1b). It was composed of tapering spindle and ovoid/ rounded cells with hyperchromatic nuclei, with eosinophilic cytoplasm. The tumour exhibited varying cellularity (Fig. 1c, d). A notable feature was wiry interstitial collagen that invested many of the individual cells. Multinucleate tumour giant cells were present throughout the lesion and concentrated at the periphery around pseudo-vascular spaces (Fig. 1e) and around some true vessels. The nuclei of these giant cells were identical to the tumour cells and rather crowded and hyperchromatic in appearance. No mitotic figures were seen. There was no significant nuclear pleomorphism and no necrosis was identified. Patchy collections of lymphocytes and plasma cells were present in some parts of the lesion. Immunohistochemistry showed that the spindle/ovoid cells and the multinucleate tumour giant cells were all positive for STAT6 (nuclear Fig. 1f, g) and CD34 (cytoplasmic). The tumour cells were negative for smooth muscle actin, S100, MelA, HHV8, ERG, desmin, ALK1, beta-catenin, and AE1AE3. The giant cells were negative for CD68 (not shown). The histological and immunohistochemical features were those of a GCR-SFT. The margins were clear of tumour.

Case 2

A 26-year-old white female presented with a 12-month history of a gradually expanding lesion in the inferior bulbar conjunctiva and fornix of the left eye (Fig. 2a). There was no bleeding and no pain. There was no history of trauma and no significant previous ocular or past general medical history. Examination showed a welldefined, dome-shaped pink fleshy mass of $10 \times 7 \times 2 \mathrm{~mm}$, with a broad base on the inferior bulbar conjunctiva and abutting the inferior fornix. A CT scan of the left orbit was normal. The lesion was excised. The patient remains tumour free to date (with a follow-up period of 6 months).

\section{Histopathological Findings}

The histology was very similar to case 1 except that the multinucleate giant cells very closely resembled Touton giant cells and did not show the rather hyperchromatic crowded nuclei of the giant cells observed in case 1 . No pseudo-vascular spaces were identified (Fig. 2b). The tumour cells, including the Touton-like multinucleate giant cells, displayed nuclear positivity for STAT6 (Fig. 2c) and CD34 (not shown). The giant cells were negative for CD68 (Fig. 2c). An unexpected feature was the presence of a separate Melan A and Sox10 co-expressing (Fig. 2d) melanocytic population amongst the STAT6-positive main tumour population.

Fig. 1. a External appearance of the right peri-ocular region showing the conjunctival growth. Note the well-demarcated lesion with a smooth pink surface. b Low-power haematoxylin and eosin (H\&E)-stained histological section showing a well-defined neoplasm in the stroma. c Higher-power H\&E showing varying cellularity of the lesion and collagen around spindle cells. d Higher power H\&E showing the tumour spindle cells surrounded by collagen. e Pseudo-vascular spaces within the tumour surrounded by hypercellular zones, which at higher power (bottom left inset figure) comprise a population of tumour giant cells. $\mathbf{f}$ The tumour cells are positive for STAT6 (nuclear). Brown shows positive staining. $\mathbf{g}$ The tumour giant cells are positive for STAT6 (nuclear). Brown shows positive staining.

(For figure see next page.) 

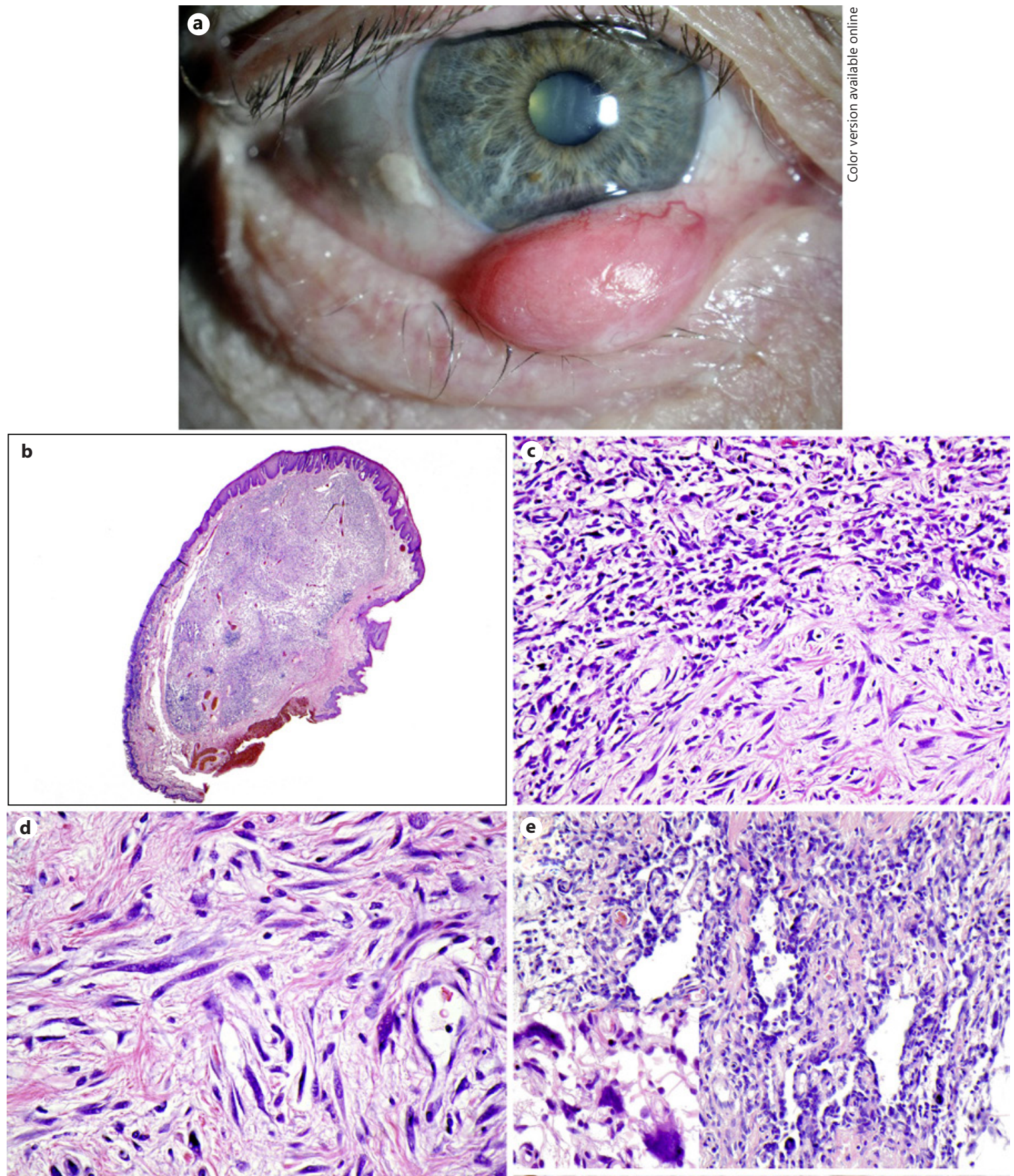

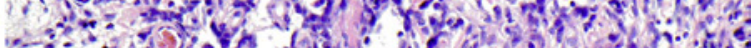

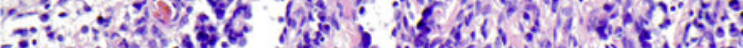

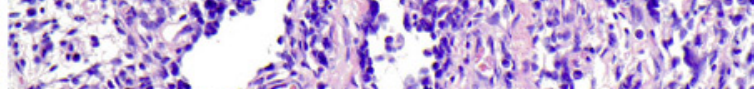

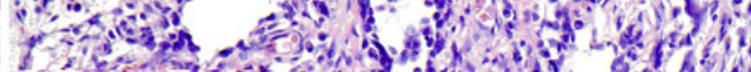

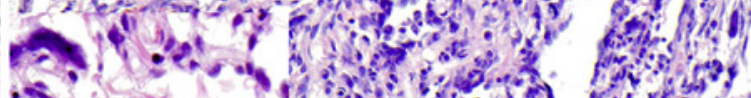

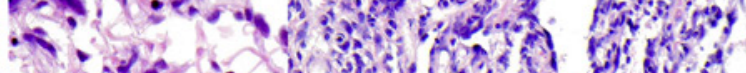

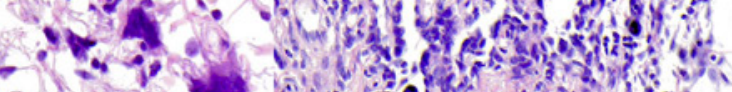

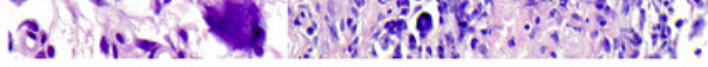
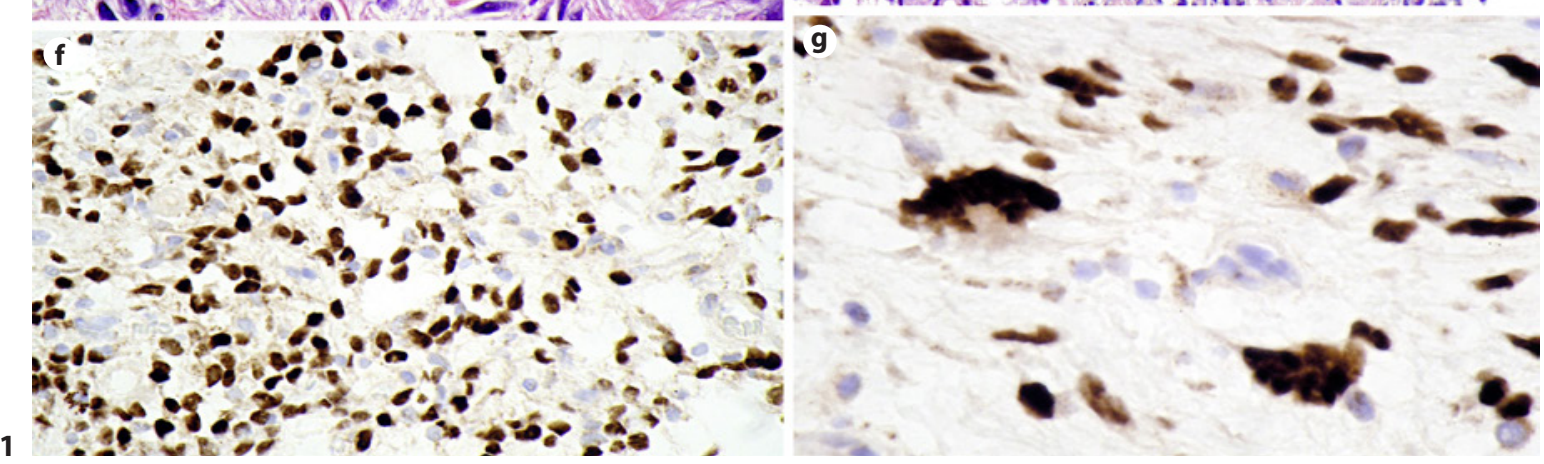
Fig. 2. a Pink fleshy smooth muscle on the left inferior bulbar conjunctiva/fornix. b Touton-like giant cells present in tumour. c The tumour cells and the Toutonlike giant cells (top right inset) are positive for STAT6 (nuclear) and negative for CD68 (bottom right inset). Brown shows positive staining. $\mathbf{d}$ A separate population of Sox 10 (brown nuclear staining) and Melan A (red cytoplasmic staining) co-expressing spindle cells within the GCR-SFT.
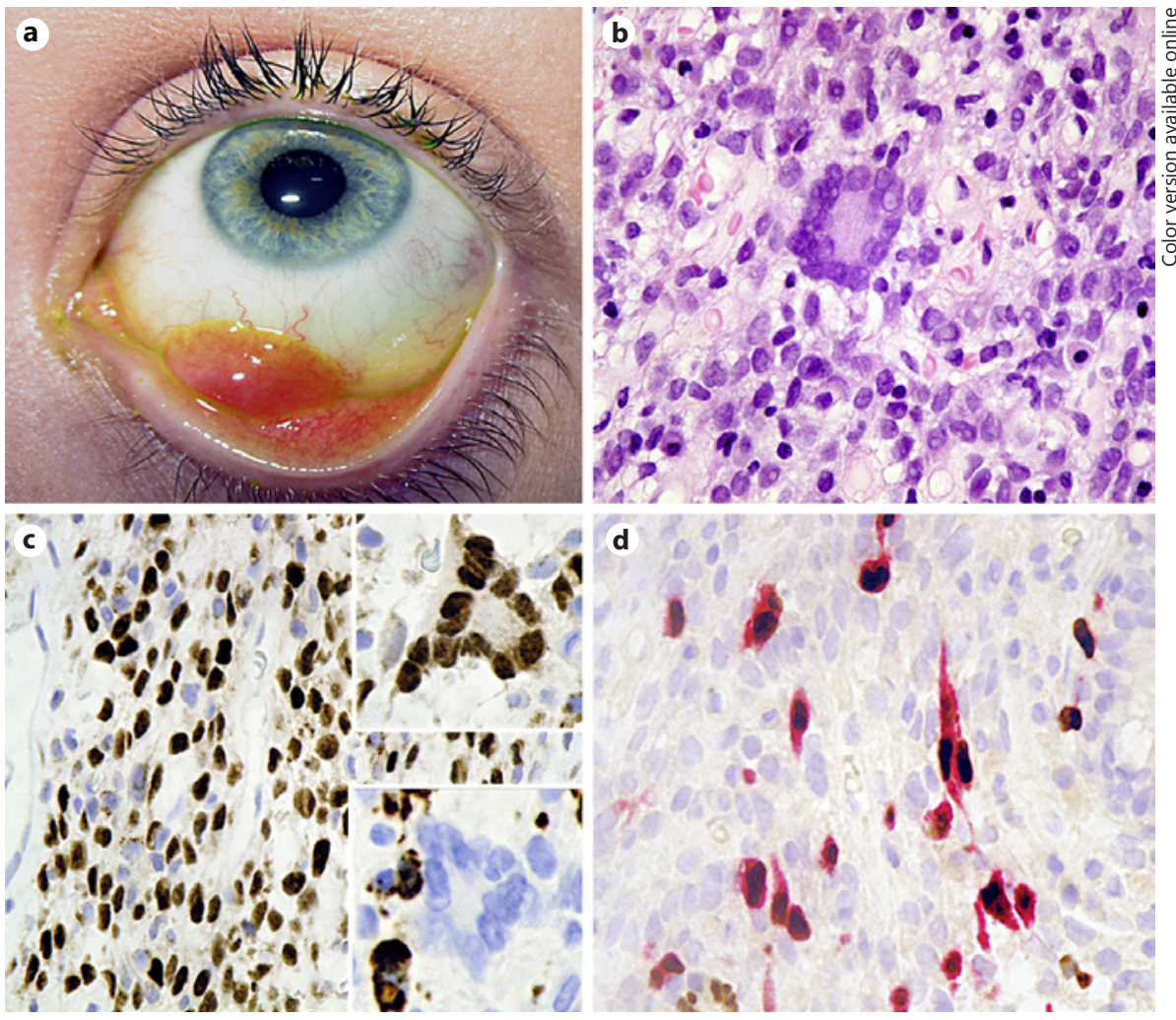

Table 1. Summarising the previous cases of conjunctival GCR-SFT including the present cases

\begin{tabular}{|c|c|c|c|c|c|c|}
\hline $\begin{array}{l}\text { Reference } \\
\text { citation }\end{array}$ & $\begin{array}{l}\text { Age } \\
\text { and sex }\end{array}$ & Location & $\begin{array}{l}\text { Size (max Clinical presentation } \\
\text { dimension), } \\
\mathrm{mm}\end{array}$ & Histology & $\begin{array}{l}\text { Immuno- } \\
\text { histo- } \\
\text { chemistry }\end{array}$ & Outcome \\
\hline
\end{tabular}

\begin{tabular}{|c|c|c|c|c|c|c|c|}
\hline 2 & $\begin{array}{l}\text { (a) } 40 \mathrm{~F} \\
\text { (b) } 43 \mathrm{M}\end{array}$ & $\begin{array}{l}\text { (a) RIF } \\
\text { (b) RM }\end{array}$ & $\begin{array}{l}\text { (a) } 14 \\
\text { (b) } 10.5\end{array}$ & $\begin{array}{l}\text { (a) Nodule enlarging over } 6 \text { months } \\
\text { (b) Few-month history of a medial } \\
\text { bulbar mass protruding through the } \\
\text { eyelids }\end{array}$ & $\begin{array}{l}\text { (a) Haemangio- } \\
\text { pericytoma } \\
\text { (b) Haemangio- } \\
\text { pericytoma }\end{array}$ & $\begin{array}{l}\text { (a) Not done } \\
\text { (b) Not done }\end{array}$ & $\begin{array}{l}\text { (a) No FU data } \\
\text { (b) No FU data }\end{array}$ \\
\hline 4 & $\begin{array}{l}65 \mathrm{M} \\
\text { (case } 5 \\
\text { from } \\
\text { reference) }\end{array}$ & $\begin{array}{l}\text { IB (side } \\
\text { not } \\
\text { specified) }\end{array}$ & $\begin{array}{l}\text { Not } \\
\text { specified }\end{array}$ & $\begin{array}{l}\text { Recently discovered painless mass } \\
\text { thought to be a cyst }\end{array}$ & GCA variant of SFT & CD34+ & No FU data \\
\hline 5 & $24 \mathrm{M}$ & RIF & 14 & $\begin{array}{l}\text { 12-month history of a painless lump } \\
\text { on the right lower eyelid }\end{array}$ & GCA variant of SFT & CD34+ & No FU data \\
\hline $\begin{array}{l}\text { Present } \\
\text { case } 1 \text {, } \\
\text { Mudhar } \\
\text { et al. }\end{array}$ & $84 \mathrm{M}$ & RIB & 10 & $\begin{array}{l}\text { Several-year history of a slowly } \\
\text { growing right lower lid mass, affecting } \\
\text { the down-gaze visual field }\end{array}$ & GCA variant of SFT & $\begin{array}{l}\text { STAT6+ } \\
\text { CD34+ }\end{array}$ & $\begin{array}{l}\text { No recurrence to } \\
\text { date (12 months) }\end{array}$ \\
\hline
\end{tabular}

R, right; L, left; IF, inferior fornix; M, medial; IB, inferior bulbar; GCA, giant cell angiofibroma; SFT, solitary fibrous tumour; FU, follow-up. 


\section{Discussion}

Table 1 lists the previous cases of suspected and confirmed GCR-SFT occurring in the conjunctiva [2-5]. This case report documents two more cases of GCR-SFT from the conjunctival surface. It is the first to demonstrate STAT6 positivity of the tumour cells and the giant cells in the conjunctiva. STAT6 has a very high level of specificity (100\%) and sensitivity (98\%) by immunohistochemistry to detect the NAB2-STAT6 fusion protein in the nuclei of SFT tumour cells, compared to histological mimics [6-8]. Only a very small handful of other softtissue neoplasms express STAT6; these include dedifferentiated liposarcoma, undifferentiated pleomorphic sarcoma, and deep fibrous histiocytoma [6]. However, their morphology is quite different to that of GCR-SFT.

The second case showed cells mimicking Touton giant cells, which initially lead to an interpretation of a juvenile xanthogranuloma prior to the immunohistochemical testing. The nuclei were lined up around the periphery of the giant cells forming rings. Such Touton-like giant cells have not been documented before in GCR-SFT. Secondly, the same case showed co-expressing Melan A- and Sox10-positive non-pigmented spindle cells amongst the GCR-SFT. The latter could be explained by a collision between the GCR-SFT and a subepithelial melanocytic nevus. A second possibility is that the GCR-SFT has caused hyperplasia of stromal melanocytes (similar to what happens in skin when dermal-based benign melanocytes undergo hyperplasia). Another possibility is that the GCRSFT is undergoing divergent melanocytic differentiation. A further possibility is entrapped benign Schwann cells within peripheral nerves reacting with the Sox10. However, the Sox10-positive cells co-expressed Melan A which Schwann cells do not.
A recent study has examined the promiscuous staining patterns of MiTF (microphthalmic associated transcription factor) in fibro-histiocytic soft tissue neoplasms such as histiocytoma angiofibroma, fibromatosis, keloid, atypical fibroxanthoma, dermal scar, and dermatofibrosarcoma protuberans. SFT and its variants were not included. The study found that MiTF stained a subset of cells in fibromatosis and dermatofibrosarcoma protuberans. The study did not employ Melan A and Sox10 markers, and so the conclusion of this paper was incomplete [9].

In both cases, complete excision has been curative, with no localized recurrence or metastasis to date.

\section{Statement of Ethics}

The study was conducted ethically in accordance with the World Medical Association Declaration of Helsinki. The subjects have given written informed consent to publish the cases (including publication of images).

\section{Disclosure Statement}

The authors have no conflicts of interest to declare.

\section{Funding Sources}

This study attracted no funding.

\section{Author Contributions}

H.S.M. wrote the paper and contributed the pathology figures. M.P., A.C., and T.J. contributed all clinical data and wrote and edited the manuscript.

\section{References}

1 Dei Tos AP, Seregard S, Calonje E, Chan JK, Fletcher CD. Giant cell angiofibroma. A distinctive orbital tumor in adults. Am J Surg Pathol. 1995 Nov;19(11):1286-93.

2 Grossniklaus HE, Green WR, Wolff SM, Iliff NT. Hemangiopericytoma of the conjunctiva. Two cases. Ophthalmology. 1986 Feb;93(2): 265-7.

3 Pecorella I, Cruciani F, Russo V. A solitary fibrous tumour of the eyelid. Med Princ Pract. 2014;23(2):170-3.

4 Hayashi N, Borodic G, Karesh JW, Tolentino MJ, Remulla HD, Van Wesep RA, et al. Giant cell angiofibroma of the orbit and eyelid. Ophthalmology. 1999 Jun;106(6):1223-9.

5 Song A, Syed N, Kirby PA, Carter KD. Giant cell angiofibroma of the ocular adnexae. Arch Ophthalmol. 2005 Oct;123(10):1438-43.

6 Cheah AL, Billings SD, Goldblum JR, Carver P, Tanas MZ, Rubin BP. STAT6 rabbit monoclonal antibody is a robust diagnostic tool for the distinction of solitary fibrous tumour from its mimics. Pathology. 2014 Aug;46(5):389-95.

7 Doyle LA, Vivero M, Fletcher CD, Mertens F, Hornick JL. Nuclear expression of STAT6 distinguishes solitary fibrous tumor from histo- logic mimics. Mod Pathol. 2014 Mar;27(3): 390-5.

8 Yoshida A, Tsuta K, Ohno M, Yoshida M, Narita Y, Kawai A, et al. STAT6 immunohistochemistry is helpful in the diagnosis of solitary fibrous tumors. Am J Surg Pathol. 2014 Apr;38(4):552-9.

9 Mohanty SK, Sharma S, Pradhan D, Kandukuri SR, Farahani N, Barry C, et al. Microphthalmia-associated transcription factor (MiTF): promiscuous staining patterns in fibrohistiocytic lesions is a potential pitfall. Pathol Res Pract. 2018 Jun;214(6):821-5. 